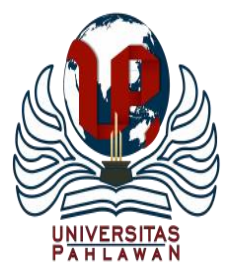

Edukatif : Jurnal Ilmu Pendidikan Volume 3 Nomor 5 Tahun 2021 Halm 2911 - 2918

EDUKATIF: JURNAL ILMU PENDIDIKAN

Research \& Learning in Education

https:/ledukatif.org/index.php/edukatif/index

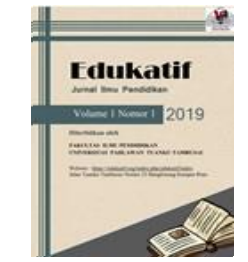

\title{
Analisis Teori Kepemimpinan dalam Organisasi
}

\author{
Wulandari $^{1 凶}$ Rusdinal $^{2}$, Nurhizrah Gistituati ${ }^{3}$ \\ Universitas Negeri Padang, Indonesia ${ }^{1,2,3}$ \\ E-mail : wulandariap499@gmail.com ${ }^{1}, \underline{\text { rusdinal@ fip.unp.ac.id }}^{2}, \underline{\text { icha_up@ @ahoo.com }}^{3}$
}

\begin{abstract}
Abstrak
Artikel ini memberikan beberapa penjelasan penting untuk berbagai definisi dan teori kepemimpinan. Penelitian ini menggunakan metode tinjauan pustaka. Dengan cara ini, penulis mengumpulkan data dan dokumentasi dari sumber berbeda yang berkaitan dengan topik yang dibahas dalam artikel ini. Tujuan artikel ini adalah untuk menjelaskan secara sistematis dan realistis fakta, karakteristik, dan hubungan antara fenomena yang diteliti. Penelitian ini menggunakan pendekatan penelitian analisis isi, yang juga dikenal sebagai meta-analisis, khususnya metode analisis isi dan menggabungkan beberapa jenis penelitian sebelumnya. Kepemimpinan adalah proses mempengaruhi orang lain di dalam dan di luar organisasi untuk mencapai arus yang diinginkan dalam situasi atau kondisi tertentu. Ini biasanya mencakup beberapa otoritas seperti ancaman, penghargaan, penghargaan, otoritas, dan pencegahan. Dari sudut pandang teoretis, anda dapat menemukan berbagai jenis teori kepemimpinan: sifat kepemimpinan, perilaku, dan situasi. Teori kepemimpinan karakteristik berusaha untuk mengidentifikasi karakteristik fisik, mental, dan pribadi yang unik yang terkait dengan kepemimpinan yang sukses. Hal ini didasarkan pada penelitian yang menggabungkan karakteristik yang berbeda dengan kriteria tertentu untuk sukses. Teori kepemimpinan karakteristik berusaha untuk mengidentifikasi karakteristik fisik, mental dan pribadi yang unik yang terkait dengan kepemimpinan yang sukses.
\end{abstract}

Kata Kunci: kepemimpinan, organisasi.

\begin{abstract}
This article provides some important explanations for the various definitions and theories of leadership. This research uses the library method. In this way, the authors collect data and documentation from different sources related to the topics discussed in this article. The purpose of this article is to systematically and realistically explain the facts, characteristics, and relationships between the phenomena studied. This study uses a content analysis research approach, also known as meta-analysis, specifically an analytical method that combines several types of previous research. Leadership is the process of influencing others inside and outside the organization to achieve what is desired in certain situations or conditions. It usually includes several authorities such as threats, rewards, rewards, authority, and deterrence. From a theoretical point of view, you can find different types of leadership theories: leadership traits, behaviors, and situations. Leadership Theory seeks to identify the unique physical, mental, and personal characteristics associated with successful leadership. It is based on research that combines different characteristics with certain criteria for success. Leadership theory seeks to identify the unique physical, mental, and personal characteristics associated with successful leadership.
\end{abstract}

Keywords: leadership, organization.

Copyright (c) 2021 Wulandari, Rusdinal, Nurhizrah Gistituati

$\triangle$ Corresponding author

Email : wulandariap499@gmail.com

DOI : https://doi.org/10.31004/edukatif.v3i5.993

ISSN 2656-8063 (Media Cetak)

ISSN 2656-8071 (Media Online)

Edukatif : Jurnal Ilmu Pendidikan Vol 3 No 5 Tahun 2021 p-ISSN 2656-8063 e-ISSN 2656-8071 


\section{PENDAHULUAN}

Kepemimpinan dianggap sangat penting karena dua alasan. Salah satunya adalah fakta bahwa kinerja suatu unit, instansi atau organisasi seringkali dipengaruhi oleh pergantian kepemimpinan. Kedua, hasil penelitian menunjukkan bahwa salah satu faktor internal yang mempengaruhi keberhasilan organisasi adalah kepemimpinan, termasuk proses kepemimpinan di semua tingkatan organisasi, serta keterampilan dan perilaku pemimpin yang relevan (Mulyasa 2011) Fakta dan/atau ide dan kesimpulan tidak dapat disangkal. Seperti yang dipahami semua orang yang terlibat, bahkan untuk hal-hal teknis seperti mengubah tata ruang kantor, mengubah kursi, mengubah warna dinding, istilah itu terdengar seperti "perubahan arah, perubahan arah". Jadi kepemimpinan adalah fenomena yang kompleks, dan selalu menarik untuk dipelajari.

Artikel ini memuat berbagai teori-teori kepemimpinan yang bertujuan agar para pimpinan baik itu dalam dunia pendidikan maupun organisasi lainnya menjadikan artikel ini menjadi pedoman dalam memimpin organisasinya. Teori yang ada dalam artikel ini merupakan gabungan dari beberapa pendapat para ahli yang dihadirkan menjadi satu pembahasan.

Dalam literatur lain, kepemimpinan dapat dipelajari dari tiga aspek: (1) pendekatan karakteristik (2) pendekatan gaya atau perilaku, atau gaya pendekatan kepemimpinan. (3) Mendekati Kontingensi Dalam perkembangan selanjutnya, fokus penelitian adalah bagaimana menjadi pemimpin yang efektif, termasuk meningkatkan kesadaran akan kemampuan Tuhan untuk menjadi pemimpin yang profesional dan beretika.

\section{METODE PENELITIAN}

Penelitian ini menggunakan metode tinjauan pustaka. Dengan cara ini, penulis mengumpulkan data dan dokumentasi dari sumber berbeda yang berkaitan dengan topik yang dibahas dalam artikel ini. Tujuan artikel ini adalah untuk menjelaskan secara sistematis dan realistis fakta, karakteristik, dan hubungan antara fenomena yang diteliti. Penelitian ini menggunakan pendekatan penelitian analisis isi, yang juga dikenal sebagai meta-analisis, khususnya metode analisis isi dan menggabungkan beberapa jenis penelitian sebelumnya.

\section{HASIL DAN PEMBAHASAN PENELITIAN}

\section{Definisi Kepemimpinan}

Definisi kepemimpinan juga berbeda ketika orang mencoba mendefinisikan konsep kepemimpinan. Didefinisikan secara luas, kepemimpinan melibatkan proses mempengaruhi penetapan tujuan organisasi, mendorong perilaku pengikut untuk mencapai tujuan tersebut, dan mempengaruhi tim dan budaya. Hal ini juga mempengaruhi menjelaskan peristiwa kepada pengikut, mengatur kegiatan untuk mencapai tujuan tersebut, menjaga hubungan kerjasama dan kerja tim, dan mendapatkan dukungan, dan kerjasama dari orangorang di dalam atau di luar organisasi.

Konsep kepemimpinan merupakan dasar untuk analisis proses dan dinamika dalam sebuah organisasi. Karena itu, sebenarnya banyak penelitian dan diskusi yang membahas definisi kepemimpinan yang membingungkan. Menurut Katz dan Kahn (B 2012) definisi lain dari kepemimpinan dapat dibagi menjadi tiga kelompok utama: "sebagai atribut atau kelengkapan dari suatu kedudukan, sebagai karakteristik seseorang, dan sebagai kategori perilaku".

Di atas segalanya, gagasan tentang atribut jabatan atau kepemimpinan secara keseluruhan dikemukakan oleh Janda (Harianto 2014) sebagai berikut. Kepemimpinan adalah jenis khusus dari hubungan kekuasaan yang didefinisikan oleh asumsi anggota kelompok bahwa salah satu anggota kelompok diberdayakan untuk menentukan pola perilaku yang terkait dengan kinerja mereka sebagai seorang pemimpin. Seorang anggota 


\section{Analisis Teori Kepemimpinan dalam Organisasi - Wulandari, Rusdinal, Nurhizrah Gistituati DOI: https://doi.org/10.31004/edukatif.v3i5.993}

grup. seperti dicatat oleh (Kunandar 2009), pemimpin adalah agen perubahan dan mereka yang bertindak untuk mempengaruhi orang lain lebih dari orang lain mempengaruhi diri mereka sendiri.

Sehubungan dengan ketiga interpretasi ini, (Mulyasa 2013) menyatakan bahwa Kepemimpinan terdiri dari anggota kelompok yang berbeda yang dapat dengan jelas dibedakan dari anggota lain dalam hal perilaku, sifat, individu, pemikiran, atau struktur kelompok. saya mengklaim Karena definisi kepemimpinan mencakup karakteristik, perilaku, dan posisi individu dalam suatu kelompok, pemahaman ini tampaknya menyatukan tiga kategori pemikiran secara keseluruhan. Sekelompok kegiatan untuk mencapai suatu tujuan.

\section{Pendekatan Sifat}

Sebuah teori yang berusaha untuk mengidentifikasi karakteristik yang berbeda (fisik, mental, kepribadian) yang terkait dengan kepemimpinan yang sukses. Itu bergantung pada penelitian yang menghubungkan berbagai properti dengan kriteria keberhasilan tertentu.

Pendekatan sifat berusaha memahami kepemimpinan berdasarkan keyakinan bahwa pemimpin yang baik memiliki "sifat bawaan" sejak lahir dengan ciri fisik dan kepribadian. Stogdill (Sutrisno 2013) menyatakan: Ciri-ciri fisik dan kepribadian pemimpin adalah: usia, penampilan fisik, kelancaran, intuisi, dorongan, dominasi, kepercayaan diri, ekstroversi, keinginan untuk berhasil, efektif kepemimpinan. dan banyak lagi. (Kartono 2014) Pemimpin yang sukses, energi yang tak terbatas, intuisi yang tajam, gagasan yang luas, kemampuan yang luar biasa seperti pengaruh / bujukan yang tak terbantahkan.

Di sisi lain, dari penjelasan (Ambarwati 2015) dan (armelia and Afriansyah 2019), karakteristik yang dapat membentuk kepemimpinan yang efektif dapat diringkas sebagai berikut: Sifat-sifat dan Keterampilan dari Kepemimpinan Yang Efektif: (1) Kepribadian (Tingkat semangat (energi), Percaya diri, Tahan stress, Kedewasaan emosi, Integritas, Ekstroversi (2) Motivasi (Orientasi kekuasaan tersosialisasi, Kebutuhan berprestasi kuat, Kurang memerlukanafiliasi, Kebanggan diri? (self-efficacy), (3) Keterampilan, (Hubungan antar pribadi, Kognitif, Teknis, Konseptual).

Kualitas kepemimpinan yang diidentifikasi di atas dianggap menekankan kepribadian "maskulin atau maskulin" dan telah dikritik karena mengandung bias gender. Selain itu, ratusan upaya penelitian telah gagal menemukan aset yang dapat menjamin kepemimpinan yang sukses (Usman 2012). Dalam hal ini, ajaran "Sastra Theta" dan "Astabrata" (8 kebajikan) yang dijelaskan oleh R. Ng sangat penting. Elemen Zip Pro (Wahjosumidjo 2011) Sastra Sessa adalah ceramah yang diberikan Rahden Rama kepada adiknya Prabhu Dasarata tentang langkah-langkah menuju pemerintahan. Ajaran Astabratha meliputi nasehat yang diberikan kepada Gunawan Wibisana pada saat penobatan raja, dimana Raden Rama memimpin Alenka atas nama saudaranya (Rahwana) Kualitas kepemimpinan yang diidentifikasi di atas dianggap menekankan kepribadian "maskulin atau maskulin" dan telah dikritik karena mengandung bias gender. Selain itu, ratusan upaya penelitian telah gagal menemukan aset yang dapat menjamin kepemimpinan yang sukses (Wahyudi 2012); (Yudiaatmaja 2013) Dalam hal ini, ajaran "Sastra Theta" dan "Astabrata" (8 kebajikan) yang dijelaskan oleh R. Ng sangat penting. Elemen Zip Pro (Syafaruddin and Asrul 2015). Sastra Sessa adalah ceramah yang diberikan Rahden Rama kepada adiknya Prabhu Dasarata tentang langkah-langkah menuju pemerintahan. Ajaran Astabratha meliputi nasehat yang diberikan kepada Gunawan Wibisana pada saat penobatan raja, dimana Raden Rama memimpin Alenka atas nama saudaranya (Rahwana).

Teori ini menekankan kualitas pribadi pemimpin. Yang mendasari teori ini adalah asumsi bahwa beberapa orang dilahirkan sebagai pemimpin dan memiliki karakteristik tertentu yang tidak dimiliki orang lain (energi tak terbatas, intuisi mendalam, kejernihan jempol yang luar biasa, daya persuasif, dll.). Teori kepemimpinan ini berpandangan bahwa keberhasilan manajer adalah karena kemampuannya yang luar biasa sebagai seorang pemimpin.

Intelegensia. Dalam tinjauan terhadap 33 penelitian, Ralph Stogdir menemukan bahwa para pemimpin sangat cerdas dengan pendukungnya. Ini adalah salah satu penemuan penting. Perbedaan besar dalam kecerdasan antara pemimpin dan pengikut dapat membingungkan. Misalnya, seorang pemimpin dengan IQ 


\section{Analisis Teori Kepemimpinan dalam Organisasi - Wulandari, Rusdinal, Nurhizrah Gistituati DOI: https://doi.org/10.31004/edukatif.v3i5.993}

yang cukup tinggi mencoba mempengaruhi kelompok yang anggotanya memiliki IQ rata-rata mungkin tidak mengerti mengapa anggotanya tidak memahami masalahnya. Kepribadian.Beberapa temuan menunjukkan bahwa ciri-ciri kepribadian seperti perhatian, kredibilitas, integritas pribadi, dan kepercayaan diri berhubungan dengan kepemimpinan yang efektif. Karakteristik Fisik. Studi tentang hubungan antara kepemimpinan yang efektif dan karakteristik fisik seperti usia, tinggi badan, berat badan, dan penampilan telah menghasilkan berbagai hasil. Menjadi lebih tinggi dan lebih berat daripada rata-rata kelompok jelas tidak membantu Anda menjadi pemimpin tim.

\section{Pendekatan Gaya (the Style Approach)}

Teori gaya kepemimpinan bertujuan untuk mengetahui apakah perilaku atau perilaku seorang pemimpin mempengaruhi atau mempengaruhi pengikutnya dalam mencapai tujuannya. Perilaku dan perilaku ini dapat dipahami sebagai dua yang berbeda secara mendasar tetapi terkait. Artinya (1) Fokus pada penyelesaian tugas atau pekerjaan/produksi. (2) Fokus pada pelatihan staf untuk melaksanakan tugas / pekerjaan ini (orang/tugas). berpusat pada karyawan).

Lewin, Lippitt dan White (HAFULYON 2016) mempelajari tingkat kontrol yang ketat pada tahun 1930-an, dengan menggunakan istilah gaya kepemimpinan otokratis, demokratis, dan liberal. (1) Kepemimpinan otokratis dan manajemen maju tanpa kebebasan dan partisipasi anggota dalam pengambilan keputusan. Pemimpin bersifat otoriter, mereka lebih suka mendelegasikan wewenang dan tidak menyukai partisipasi anggota. (2) Sementara ini melibatkan kepemimpinan demokratis dan tingkat kontrol yang longgar, para pemimpin sangat aktif dalam merangsang diskusi kelompok dan pengambilan keputusan kelompok, di mana kebijakan atau keputusan dikomunikasikan bersama. Tunjukkan kepemimpinan atau anggota Inisiatif Kinerja Bersama. (3) Kepemimpinan Laziss-fire, Serahkan pada kepemimpinan dan biarkan anggota memutuskan sendiri. Keberhasilan organisasi adalah individu atau individu, karena pemimpin sebagian besar berperan pasif dan tidak memiliki kontrol/pengawasan.

House dan Mitchell (Syafaruddin and Asrul 2015) juga mengembangkan teori jalur tujuan, yang mengharuskan para pemimpin untuk meningkatkan jumlah dan variasi insentif karyawan. Kemudian kami akan menjelaskan instruksi dan prosedur tentang cara memenangkan hadiah. Kita tahu bahwa kepemimpinan difokuskan pada membimbing, mendukung, melibatkan, dan berhasil pada perilaku kepemimpinan yang memotivasi dan menjelaskan kepada karyawan.

Kepemimpinan direktif, yaitu pemimpin yang memberikan bimbingan secara rinci dan jelas tentang tujuan, sasaran, dan cara mencapainya. Tidak ada ruang untuk diskusi atau partisipasi karyawan . Kepemimpinan yang Mendukung: Nominasikan pemimpin untuk menjadi "teman" bawahan Anda dan berikan dukungan materi, keuangan, atau emosional. Kami peduli dengan kesejahteraan karyawan kami. Dalam kepemimpinan partisipatif, bagaimanapun, pengambilan keputusan dan / atau tindakan untuk meminta dan menggunakan masukan atau saran karyawan, namun keputusan dan wewenang tetap diarahkan oleh kepemimpinan. Kepemimpinan berorientasi prestasi, Kepemimpinan yang digerakkan oleh kesuksesan mewakili seorang pemimpin yang percaya bahwa dia dapat mengklaim kinerja yang luar biasa, menetapkan tujuan yang ambisius, dan berimprovisasi untuk mencapai standar kinerja tinggi bagi karyawan.

Teori dalam kategori ini dikembangkan oleh (Usman 2012) Jaringan kepemimpinan pekerja dan minat dalam produksi diukur pada skala min $=0$ dan maksimum $=9$. Jadi, skala 9,9, yang dikenal sebagai tim manajemen, dianggap sebagai gaya kepemimpinan terbaik. (Sutrisno 2013) mengembangkan ukuran perilaku kepemimpinan yang dikelompokkan menjadi empat gaya: kekuatan eksploitatif, otoritas anggun, bimbingan, dan kekuatan partisipatif. Ada juga lebih banyak teori yang dikembangkan berdasarkan orientasi perilaku pemimpin yang melihat kinerja kegiatan / produksi / hasil dan karyawan yang menjadi pelaku kegiatan. 


\section{Analisis Teori Kepemimpinan dalam Organisasi - Wulandari, Rusdinal, Nurhizrah Gistituati DOI: https://doi.org/10.31004/edukatif.v3i5.993}

\section{Pendekatan Kontingensi (The Contingency Approach)}

Karena tidak ada obat mujarab (obat mujarab) untuk semua penyakit; Demikian juga, tidak ada satu gaya kepemimpinan yang berhasil dalam semua situasi. Gaya kepemimpinan yang optimal sangat tergantung pada (1) kepribadian, kemampuan, dan keterampilan pemimpin, (2) perilaku pengikut, dan (3) kondisi lingkungan. Situasinya tinggi (Khairizah et al. 2016) Atau, seperti yang dikatakan (SONO 2020) "Inti dari situasi bersarang yang sadar konteks dalam konteks apa pun mencakup bagaimana pemimpin dan pengikutnya bergabung untuk menyempurnakan strategi perilaku pemimpin." Oleh karena itu, Gaya Kepemimpinan yang efektif atau optimal merupakan hasil penerapan strategi yang mempengaruhi karyawan dengan memperhatikan karakteristik karyawan yang memimpin (pengikut) dan konteks situasi.

Dikembangkan oleh A Fallback Model of Leadership Effectiveness, Fiedler mengasumsikan bahwa kinerja tim bergantung pada interaksi antara gaya kepemimpinan dan situasi dukungan. Kepemimpinan dianggap sebagai hubungan yang didasarkan pada kekuasaan dan pengaruh.

Hersey dan Blanchard (Nurmasyitah, AR, and Usman 2015) mengembangkan teori kepemimpinan yang pada awalnya disebut "teori siklus hidup kepemimpinan" dan kemudian disebut "teori kepemimpinan situasional". Argumen yang mendasari teori ini adalah bahwa kepemimpinan yang efektif memerlukan perpaduan yang tepat antara perilaku berorientasi tugas dan berorientasi hubungan, dengan mempertimbangkan kematangan bawahan. Berdasarkan kombinasi ini, Anda dapat menerapkan berbagai gaya kepemimpinan untuk berkomunikasi, menjual, terlibat, dan mendelegasikan seperti yang ditunjukkan di bawah ini.

Gaya Telling, Bercerita digunakan dalam situasi di mana pekerjaan sangat berorientasi dan hubungan berorientasi lemah. Karyawan belum dewasa, sehingga pemimpin perlu memberikan arahan dan arahan untuk melakukan. Berbagai tugas. Gaya Selling (menjual), gaya ini berlaku untuk pekerjaan dengan orientasi tinggi dan hubungan yang tinggi, karyawan yang cukup matang. Dalam situasi ini, pemimpin memberikan arahan secara seimbang dengan memberikan dukungan, meminta umpan balik, dan mengungkapkan penghargaan. Gaya Participating (Partisipasi), Dalam partisipasi (partisipasi), kecenderungan kerja rendah, kecenderungan interpersonal kuat, dan kematangan karyawan tinggi. Oleh karena itu, kepemimpinan lebih kooperatif dan dekat secara emosional, mengutamakan nasihat, bimbingan, dan dukungan. Sedikit atau tidak ada kepemimpinan misi. Gaya Delegating (Delegasi), Kecenderungan gaya fidusia dan pekerjaan berorientasi hubungan, cocok untuk situasi lemah, staf sangat matang Perilaku hubungan Gaya kepemimpinan Hubungan tinggi dan tugas lemah (M3) G3 Hubungan lemah dan tugas lemah Tugas tinggi dan hubungan lemah Misi dan hubungan Tinggi (M2) G2G1 (M1) G (M ) Hubungan Tinggi dan Perilaku Tugas Rendah "Mendelegasikan" "Berpartisipasi" "Penjualan" "Notice". Dalam situasi ini, pemimpin memberikan tanggung jawab penuh kepada karyawan untuk menyelesaikan tugas. pemimpin tidak memberikan instruksi, mereka hanya melaporkan dan mendukung.

Pakar lain yang mengembangkan teori kepemimpinan kontingen antara lain (Sutrisno 2013) dan (Sahadi, Taufiq, and Wardani 2020). (Wahjosumidjo 2011) mengukur gaya kepemimpinan berdasarkan respons pemimpin terhadap kepribadian karyawan. Ini disebut ukuran Least Preferred Collaborator Scale (LPC). LPC memiliki kemampuan untuk mengendalikan situasi dan digunakan untuk menentukan keyakinan seorang pemimpin bahwa apa yang diharapkan benar-benar terjadi. Manajemen situasi ditentukan oleh tiga faktor: (1) hubungan antara pemimpin dan bawahannya, (2) struktur pekerjaan, dan (3) posisi kekuasaan. Oleh karena itu, gaya kepemimpinan yang efektif tergantung pada tingkat kontrol atas situasi. Model Yeton Bloom menggambarkan pendekatan kepemimpinan yang tepat untuk pengambilan keputusan dalam berbagai situasi, memberikan kepemimpinan kelompok, konsultasi, dan otomotif. Gaya berorientasi tugas, yang mementingkan tugas atau otoritatif. Gaya berorientasi hubungan, yang mementingkan hubungan kemanusiaan. Sedangkan kondisi situasi terdiri dari tiga faktor utama, yaitu: Hubungan pemimpin-anggota, yaitu derajat baik/buruknyahubungan antara pemimpin clan bawahan. Struktur tugas, yaitu derajat tinggi/ rendahnya strukturisasi,standarisasi clan rincian tugas peketjaan. Kekuasaan posisi, yaitu derajat 
kuat/lemahnya kewenangan dan pengaruh pemimpin atas variable-variabel kekuasaan, seperti memberikan penghargaan clan mengenakan sanksi

Perkembangan selanjutnya memperkenalkan teori kepemimpinan transaksional dan kepemimpinan transformasional. (sari 2019) mengatakan seperti ini "kepemimpinan transaksional dicirikan dengan perancangan tujuan-tujuan tugas, penyediaan sumberdaya untuk mencapai tujuan-tujuan tersebut, dan penghargaan terhadap kinerja"

Dalam hal ini, (Raharjo and Nafisah 2006)menambahkan bahwa para pemimpin terus-menerus memeriksa konsep dan kebutuhan mereka untuk melihat apa yang perlu dilakukan bawahan mereka.

\section{Teori Kepemimpinan Situasional Hersey Blanchard}

Hercy dan Blanchard telah mengembangkan model kepemimpinan yang sangat didukung oleh para profesional pengembangan bisnis. Model ini disebut teori kepemimpinan situasional.

Dedikasi terhadap kepemimpinan menunjukkan bahwa seorang pemimpin memahami perilaku mereka, karakteristik pengikut mereka, dan situasi sebelum mengadopsi gaya kepemimpinan tertentu. Keterikatan ini menuntut pemimpin untuk memiliki keterampilan dalam mendiagnosis perilaku orang lain. Bebrapa model kepemimpinan Situasional.

Teori kepemimpinan situasional berfokus pada pengikut dan kedewasaan mereka. Pemimpin harus secara akurat atau intuitif menilai kematangan pengikut mereka dan menggunakan gaya kepemimpinan yang sesuai dengan level mereka. Motivasi didefinisikan sebagai kemampuan dan motivasi orang (pengikut) untuk mengambil tanggung jawab untuk mengarahkan tindakan mereka.

\section{Pendekatan Terbaru dalam Kepemimpinan}

Untuk menyimpulkan tinjauan kami tentang teori kepemimpinan, kami memperkenalkan tiga pendekatan terbaru untuk masalah ini: teori atribut kepemimpinan, kepemimpinan karismatik, dan kepemimpinan transaksional dan transformasional.

\section{Teori Atribusi Kepemimpinan}

Mengemukakan bahwa kepemimpinan semata-mata suatu atribusi yang dibuat orang mengenai individu-individu lain.

\section{Teori Kepemimpinan Karismatik}

Teori kepemimpinan karismatik merupakan perluasan dari teori atribusi. Teori ini berpendapat bahwa pengikut menunjukkan kepemimpinan yang heroik atau abnormal ketika mereka mengamati perilaku tertentu. Tujuan utama dari penelitian kepemimpinan karismatik adalah untuk mengidentifikasi perilaku yang membedakan pemimpin karismatik dan tidak seperti biasanya. Kepemimpinan Transformasional a) Pemimpin transaksi adalah pemimpin yang membimbing dan memotivasi pengikut menuju tujuan yang ditetapkan dengan memperjelas peran dan kebutuhan misi, b) Pemimpin transformasional, pemimpin yang memberikan refleksi dan inspirasi intelektual individu, klan karismatik.

\section{KESIMPULAN}

Kepemimpinan adalah proses mempengaruhi orang lain di dalam dan di luar organisasi untuk mencapai tujuan yang diinginkan dalam situasi atau keadaan tertentu. Proses pengaruh sering melibatkan berbagai kekuatan, termasuk ancaman, penghargaan, kekuasaan, dan insentif. Perkembangan teori kepemimpinan berkembang dari waktu ke waktu, tergantung pada rasa ingin tahu para ilmuwan dan peneliti. Awalnya, kepemimpinan dilihat dari perspektif yang jelas tentang sifat, karakter, atau bakat yang datang sejak lahir. Ketidakpuasan dengan konsekuensi keterikatan pada sifat-sifat ini mengarah pada keterikatan pada perilaku 
kepemimpinan. Peneliti menggunakan pendekatan yang berbeda karena kedua pendekatan tersebut kurang memuaskan. Dengan kata lain, keberhasilan seseorang tergantung pada keadaan. Perkembangan terakhir juga mendekati etos pemimpin. Teori Kepemimpinan Sifat, yang berusaha mengidentifikasi karakteristik fisik, mental, dan pribadi yang terkait dengan kesuksesan, didasarkan pada penelitian yang menghubungkan berbagai sifat dengan kriteria keberhasilan tertentu. Teori Kepemimpinan Perilaku mengeksplorasi gagasan bahwa bagaimana anda bertindak menentukan efektivitas kepemimpinan anda. Ketika mereka mencoba memahami karakteristik ini, mereka melihat dampaknya terhadap kesuksesan dan kepuasan pengikut. beberapa penelitian telah dilakukan, termasuk penelitian di University of Michigan dan Ohio State University. Teori kapabilitas atau kepemimpinan situasional adalah pendekatan kepemimpinan yang menegaskan bahwa seorang pemimpin memahami perilaku mereka, karakteristik pengikut mereka, dan situasi sebelum mengadopsi gaya kepemimpinan tertentu. Model yang dikembangkan adalah Fiedler's Emergency Leadership, Vroom and Yeton's Leadership Engagement Model, Overcoming Goal Model, Hercy Blanchard's Situational Leadership Theory, dan Vertical Combination of the Dimensional Relational Approach.

\section{DAFTAR PUSTAKA}

Ambarwati, Nia. 2015. "Gaya Kepemimpinan Yang Efektif Dalam Upaya Meningkatkan Kinerja Karyawan Pada Pt. Sumber Mas Indah Plywood.” Journal of Chemical Information and Modeling 3(3):1689-99.

Ananda, Rizki. 2017. "Penerapan Pendekatan Problem Solving Untuk Meningkatkan Hasil Belajar Pada Mata Pelajaran IPS Siswa Kelas IV SD.” Jurnal Sekolah 1(2):66-75.

armelia, yola and Hade Afriansyah. 2019. "Kepemimpinan Pendidikan." 1-8.

B, Uno Hamzah. 2012. Teori Motivasi Dan Pengukurannya. Jakarta: PT Bumi Aksara.

Hafulyon, Hafulyon. 2016. "Keragaman Konsep Kepemimpinan Dalam Organisasi." Al-Fikrah: Jurnal Manajemen Pendidikan 2(1):1.

Harianto, Anto. 2014. "Pengaruh Kepemimpinan Dan Motivasi Terhadap Kepuasan Kerja.” Universitas Sahid. Kartono. 2014. Pemimpin Dan Kepemimpinan. Jakarta: PT Raja Grafindo Persada.

Khairizah, Astria, Irwan Noor, Agung Suprapto, Jurusan Administrasi Publik, Fakultas Ilmu Administrasi, and Universitas Brawijaya. 2016. "( Studi Pada Karyawan Di Perpustakaan Universitas Brawijaya Malang )." Jurnal Administrasi Publik (JAP), Vol. 3, No. 7, Hal. 1268-1272 3(7):1268-72.

Kunandar. 2009. Guru Profesional: Implementasi Kurikulum Tingkat Satuan Pendidikan (KTSP) Dan Sukses Dalam Setifikasi Guru. Jakarta: Rajawali Pers.

Mulyasa. 2011. Manajemen Dan Kepemimpinan Kepala Sekolah. Jakarta: Bumi Aksara.

Mulyasa. 2013. Manajemen Dan Kepemimpinan Kepala Sekolah. Jakarta: PT Bumi Aksara.

Nurmasyitah, Murniati AR, and Nasir Usman. 2015. "Meningkatkan Kinerja Guru Pada Sekolah." Administrasi Pendidikan 3(2):159-68.

Raharjo, Susilo Toto and Durrotun Nafisah. 2006. “Analisis Pengaruh Gaya Kepemimpinan Terhadap Kepuasan Kerja, Komitmen Organisasi Dan Kinerja Karyawan (Studi Empiris Pada Departemen Agama Kabupaten Kendal Dan Departemen Agama Kota Semarang)." Jurnal Studi Manajemen Organisasi 3(2):69-81.

Sahadi, Otong Husni Taufiq, and Ari Kusumah Wardani. 2020. "Karakter Kepemimpinan Ideal Dalam Organisasi." Moderat: Jurnal Ilmiah Ilmu Pemerintahan 6(3):513-24.

Sari, Putri melia. 2019. "Artikel Kepemimpinan Pendidikan."

SONO, MOH. 2020. "Kepemimpinan Dalam Budaya Organisasi." 10(1):1-11.

Sutrisno, Edy. 2013. Budaya Organisasi. Jakarta: Kencana. 
2918 Analisis Teori Kepemimpinan dalam Organisasi - Wulandari, Rusdinal, Nurhizrah Gistituati DOI: https://doi.org/10.31004/edukatif.v3i5.993

Syafaruddin and Asrul. 2015. Kepemimpinan Pendidikan Kontemporer. Bandung: Citapustaka Media.

Usman, Nasir. 2012. Manajemen Mutu Kinerja Guru: Konsep, Teori Dan Model. Bandung: Citapustaka Media Perintis.

Wahjosumidjo. 2011. Kepemimpinan Kepala Sekolah: Tinjauan Teoritik Dan Permasalahannya. Jakarta: Rajawali Pers.

Wahyudi. 2012. Kepemimpinan Kepala Sekolah Dalam Organisasi Pembelajaran. Bandung: Alfa Beta.

Yudiaatmaja, Fridayana. 2013. "Issn 1412 - 8683 29." Procedia - Social and Behavioral Sciences IV(2):29_ 38. 